the M.Sc. degree by research in 1917. She collaborated with Prof. Ryan in a number of investigations, including one on the action of nitrous and nitric acids on diphenylamine carried out with the co-operation of Nobels, Ltd. Later, she set up practice as a consulting chemist in Dublin, and became public analyst for twelve Irish county councils. In this connexion, it is of interest to note that all the members of her laboratory staff are women graduate chemists. She has concerned herself vigorously with the organization of the chemical profession in Ireland and is a past president of the Irish Chemical Association. Her new sphere of activity will, unfortunately, prevent her from continuing to take an active part in the work of her profession.

\section{Educational Director of the British Council : Dr. A. E. Morgan}

Dr. A. E. Morgan has been appointed educational director of the British Council and will take up his duties early next month. The post was formerly held by Prof. B. Ifor Evans, who resigned it on appointment as principal of Queen Mary College about a year ago but has continued to assist the Council in an advisory capacity. Dr. Morgan, a native of Bristol, was educated at the then University College there, and at Trinity College, Dublin. He became lecturer in, and then professor of, English language and literature in the University College, Exeter, and later occupied a similar chair in the University of Sheffield. In 1926 he was appointed principal of University College, Hull ; and during 1935-37 he was principal and vice-chancellor of McGill University, Montreal. Dr. Morgan became chief special officer for national service, Ministry of Labour, in 1939, and was thereafter a district com. missioner for the Special Areas (Durham and Tyneside), and regional information officer at Newcastleon-Tyne. Since 1941, he has been assistant secretary, Ministry of Labour. The period for which Mr. $\mathrm{H}$. Orton, the acting educational director of the British Council, was seconded to the Council from the University of Sheffield ends on August 31, and he will then resume his duties as head of the Department of English Language at Sheffield.

\section{The R. W. Paul Instrument Fund}

TeE R. W. Paul Instrument Fund was established by a trust created under the will of Mr. R. W. Paul, who died in March 1943. The income from the fund will be administered by a committee composed of representatives of the Royal Society, the Physical Society, the Institute of Physics and the Institution of Electrical Engineers. The committee will consider and adjudicate upon applications which may be submitted for financial assistance by means of grants for the following purposes : $(a)$ for the design, construction and maintenance of novel and improved types of physical instruments and apparatus for investigations in pure and applied physical science, particularly in cases where a relatively large expenditure may be justified on experimental apparatus. (b) For the assistance of research by provision of equipment, building facilities or financial or other aid in such manner as the committee may determine in each case. Grants from the fund shall not be used to relieve expenditure in any establishment controlled by the Government, or to relieve any university or other educational establishment of its normal financial obligations. When an application is favourably re- garded by the committee, an assessor will be appointed to advise in detail on the merits of the application, the feasibility of producing the desired result by means of the proposed instrument or apparatus, the urgency of the need for it and the probable cost of execution of the work.

After a grant has been made, the assessor will report to the committee not less than once every three months on the progress of the work. He may in his discretion recommend additional grants for running and maintenance costs and salaries for the time being of investigators and assistants engaged in a particular investigation, provided that no research fellowship or research scholarship is thus created. The committee will decide the ultimate destination and ownership of all instruments and apparatus produced by means of grants from the fund. Any invention or improvement in existing inventions made by a grantee must be communicated forthwith to the committee, and no grantee may apply for, or obtain, patent rights for such invention without the previous sanction in writing of the committee. Applications may be submitted by any worker or group of workers in Great Britain. Applicants must be British subjects and their qualification in physical research must be supported by the signed recommendations of not less than two of the following persons : (i) president of the Royal Society (if a physicist), or alternatively, the secretary of the Royal Society dealing with physical subjects; (ii) president of the Physical Society ; (iii) president of the Institute of Physics ; (iv) president of the Institution of Electrical Engineers. Applications should be addressed to the Assistant Secretary of the Royal Society, Burlington House, London, W.1.

\section{Industrial Research Committee of the Federation of British Industries}

AT a recent meeting of the Grand Council of the Federation of British Industries, it was announced that Mr. B. J. A. Bard has been appointed head of the F.B.I. Research Secretariat and secretary of the F.B.I. Industrial Research Committee. Mr. Bard carried out fuel research under the late Prof. W. A. Bone in the Chemical Technology Department of the Imperial College of Science and Technology, and then read for the Bar; he practised at the Bar until the outbreak of war, after which he worked first with the Coal Commission and, later, on various industrial production and research problems at the Ministries of Supply and Aircraft Production. The duties and functions of the research secretariat will include the encouragement and fostering of industrial and national interest in research, maintaining contact with all industrial research organizations, and providing a service whereby advice, assistance and information can be obtained and contacts made. Close touch is being maintained with the Department of Scientifie and Industrial Research, which is represented on the F.B.I. Industrial Research Committee. A first task will be the organization of a survey of existing research facilities in Britain. Another immediate plan of the Industrial Research Committee is a proposal for a two-day conference, to be held in London in the autumn, of those who are organizing or conducting research in industry, in order that they may present their views and give the results of their experience to industry.

The Industrial Research Committee of the Federation of British Industries is constituted as follows: Sir William Larke (chairman), Dr. S. B. Bagley, Sir 